Онокало В. Г., к.е.н., доцент (Національний університет водного господарства та природокористування, м. Рівне)

\title{
ТЕОРЕТИЧНІ АСПЕКТИ ТА ОЦІНКА ЕФЕКТИВНІСТІ ІНВЕСТИЦІЙ У РОЗВИТОК ПЕРСОНАЛУ ПІДПРИЕМСТВА
}

У статті комплексно висвітлюються теоретичні аспекти різних підходів до оцінки ефективності інвестицій у розвиток персоналу підприємства. Показано, що у зв'язку з тим, що існує велика кількість показників для оцінки ефективності інвестицій в персонал підприємства, слід у кожному випадку вивчити конкретні умови, визначити найкращий інвестиційний критерій, який може бути успішно застосований лише в системі взаємопов'язаних показників.

Ключові слова: інвестиції, людський капітал, персонал підприємства.

Постановка проблеми. Люди э найбільш важливим елементом продуктивних сил і головним джерелом розвитку економіки, тобто їхня майстерність, освіта, підготовка, мотивація діяльності. Головним елементом продуктивних сил і найважливішим виробничим ресурсом суспільства виступає робоча сила.

Головним критерієм оцінки ефективності підприємств в досягненні конкурентних переваг і забезпеченні якісних параметрів економічного росту виступає людський капітал, який являє собою сукупність природних здібностей, дарувань, творчого потенціалу, морально-психологічного і фізичного здоров'я, накопичених і вдосконалених у результаті навчання і професійного досвіду, необхідних для певної діяльності, що приносить дохід їх власникові.

Основною проблемою, з якою доводиться зустрічатися сучасним підприємствам, є оцінка ефективності вкладень у персоналу підприємства. Складності, що виникають при цьому, у певній мері пояснюються тим, що інвестиції в персонал підприємства мають ряд особливостей, що відрізняють їх від інших видів інвестицій, що вимагає необхідність розробки спеціальних методів оцінки. Інвестиції у розвиток персоналу підприємства повинні принести віддачу у вигляді підвищення результативності їі діяльності. Вони виправдані тільки в тому випадку, якщо вони мають досить високий рівень окупності й рентабельності. Тому питання оцінки ефективності інвестицій у розвиток персоналу підприємства досить актуальне, особливо в сучасних економічних умовах. 
Аналіз досліджень і публікацій. Формування теорії людського капіталу й ефективності інвестицій у людський капітал відноситься до 60-80 рр. XX в. і пов'язано з роботами вчених-економістів: Т. Шульца, Г. Беккера, Т. Бойдела, Е. Денісона, Дж. Кендрика, А. Маршалла, Ф. Махлупа, П. Сенджа, Л. Туроу та інших.

Приблизно в цей же період дискусія про людський капітал одержує широкий резонанс у вітчизняній науці, особливо наприкінці XX століття. Значний внесок в її рішення внесли В. Антонюк, Д. Богині, О. Грішнова, А. Денисова, С. Злупка, А. Колота, І. Кравченко, Е. Лібанова, Д. Мельничук, Г. Назарова, Д. Ярова, Л. Шевчук та ін.

На наше переконання, подальшої розробки потребують теоретичні та прикладні аспекти визначення ефективності інвестицій у розвиток персоналу на мікроекономічному рівні.

Постановка завдання. Провести теоретичні дослідження поглядів щодо ефективності інвестицій в розвиток персоналу підприємства, проаналізувати сучасні концепції їх оцінки та обґрунтувати показники оцінки ефективності інвестицій в розвиток персоналу підприємства.

Основні результати дослідження. Концепція людського капіталу отримала міжнародне визнання після присудження двох Нобелівських премій з економіки за внесок у розвиток теорії людського капіталу Т. Шульцу в 1979 р. і Г. Беккеру в 1992 р. Не дивлячись на те, що основний внесок у популяризацію ідеї людського капіталу був внесений Шульцем (Schultz, 1971 р.), класикою сучасної економічної думки став трактат Беккера. В основу аналізу він поклав уявлення про людську поведінку, як раціональне й доцільне, застосовуючи такі поняття, як ціна, альтернативні витрати і т.п. до найрізноманітніших аспектів людського життя, використовуючи також ті, які традиційно знаходилися у віданні інших соціальних дисциплін. Сформульована ним концепція стала основою для всіх подальших досліджень у цій області.

Людський капітал, на думку Г. Беккера, - це наявний у кожного запас знань, навичок, умінь і мотивацій. Інвестиціями в нього можуть бути освіта, накопичення професійного досвіду, географічна мобільність, пошук інформації. Спочатку інтереси дослідника були пов'язані з оцінкою економічної віддачі.

Як зазначають теоретики людського капіталу, витрати, які збільшують продуктивні якості і характеристики індивіда, можна розглядати як інвестиції, так як поточні витрати здійснюються з тим розрахунком, що вони будуть багаторазово компенсовані зрослим потоком доходів у майбутньому. 
К. Макконнелл і С. Брю виділяють наступні види інвестицій в персонал підприємства:

- витрати на освіту, які включають загальну і спеціальну, формальну і неформальну підготовку на робочому місці;

- витрати на охорону здоров'я, які складаються з витрат на профілактику захворювань, медичне обслуговування, дієтичне харчування, поліпшення житлових умов;

- витрати на мобільність, завдяки яким працівники мігрують 3 місць з відносно низькою продуктивністю в місця з відносно високою продуктивністю [1].

А.В. Кирьянов основними видами інвестицій в персонал підприємства вважає інвестиції в спеціальну підготовку, фізичний стан і емоційну поведінку працівників. Він пропонує їх розширення з цільовою орієнтацією на формування у працівника почуття лояльності (прихильності) до організації [2].

На сьогодні одним з найважливіших компонентів вкладень у людський капітал в усіх країнах $€$ витрати на навчання на виробництві. У будь-якому навчальному проекті до $80 \%$ знань припадає на самостійне навчання. Особливо це стосується професій фахівцівдослідників, вчителів, інженерів, експертам з комп'ютерів і т.д., які покликані безперервно оновлювати кваліфікацію через індивідуальне вивчення літератури, використання незалежних навчальних програм, навчання на прикладі діяльності, досвіду і оцінок (думок) інших людей [3].

Необхідність побудови системи вимірювання ефективності HRпроектів очевидна. Потрібно не оптимізувати витрати на персонал, а для досягнення компанією бізнес-цілей ефективно інвестувати в нього. Інвестувати в мотивацію, навчання, розвиток співробітників, що неодмінно дозволить отримати довгострокову економічну окупність в майбутньому [4, С.19].

У ринковій економіці складною $є$ проблема прийняття рішень щодо інвестицій. Раціональні інвестори (держава, фірми, родини й індивід) будуть вкладати грошові кошти тільки в тому випадку, якщо будуть упевнені, що ризик від проекту буде мінімальним і в майбутньому буде потік додаткового чистого доходу від даних капіталовкладень. 3 економічної точки зору інвестиції будуть виправдані, якщо вони будуть мати досить високий рівень окупності.

Для оцінки ефективності інвестиційних вкладень в людський капітал використовують цілий ряд критеріїв та показників. У економічній літературі використовуються наступні показники ефективності інвестицій в людський капітал:

1. максимізація різниці між прибутком і витратами; 
2. період окупності (віддача) інвестицій;

3. чиста поточна (приведена) вартість;

4. співвідношення витрат і прибутку;

5. відношення різниці граничних доходів до різниці граничних витрат;

6. щорічний чистий дохід;

7. внутрішня норма віддачі.

Перший показник був положений в основу моделі вимірювання ефективності інвестицій в навчання яка розроблена Дональдом Кірпатріком [5]. Теоретично можна підрахувати віддачу на інвестиції на навчання по формулі:

$$
R O I=\frac{D-Z}{Z},
$$

де ROI (рентабельність інвестиційна) - віддача на інвестиції в навчання;

D - приріст доходу, принесений підрозділом, який навчався;

$Z$ - витрати на навчання (прямі витрати на оплату тренера, оренду приміщення, недоотриманий прибуток через відсутність співробітників на робочому місці).

Розраховану величину відстежують в динаміці, що дозволяє встановити, як співвідносяться витрати на підготовку кадрів і доходи підприємства. Але точної відповіді на питання, яку віддачу в грошових одиницях принесли вкладення в підвищення кваліфікації персоналу, таким способом не отримати. Зміна економічних показників роботи фірми не залежить прямо від результатів проведеного навчання. На дохід впливає безліч факторів: кон'юнктура ринку, цінова політика, рекламні акції, дії конкурентів, кадрові перестановки і т.п. Виділити, яка частина прибутку зароблена «завдяки» проведеним тренінгам, практично неможливо [5].

Однак оцінка професійного навчання не повинна здійснюватися лише з позицій концепції людського капіталу, рівня одного працівника, вона має проводитися на рівнях структурного підрозділу, організації та держави в цілому. Між тим оцінити ефективність багатьох освітніх і професійних програм досить складно, оскільки вони у ряді випадків створюються не для формування конкретних професійних умінь і навичок, а для розвитку певного типу мислення та поведінки. Так, це стосується, насамперед, тих навчальних програм, що спрямовані на розвиток молодих фахівців з вищою освітою організації, з метою підготовки резерву керівних кадрів.

Оцінювання економічної ефективності професійного навчання персоналу передбачає виділення таких аспектів: особистісного, сус- 
пільного, аспекту навчального закладу та організації. Особистісний аспект зводиться до методів економічної оцінки інвестування у людський капітал. Для визначення ефективності людського капіталу економісти звертаються до техніки аналізу «витрати-вигоди». Цей аналіз поділяється на три етапи:

- ідентифікація вигод і їх вартісна оцінка з урахуванням фактору часу;

- ідентифікація витрат і їх вартісна оцінка також з урахуванням фактору часу;

- порівняння приведених до одного моменту часу величин витрат і вигод [6].

Для приведення вигод і витрат до одного моменту праці застосовують метод дисконтування. Розрахунок вигод від вкладень у людський капітал передбачає проведення прогресивного дисконтування вигод, порівняння їх з поточними витратами, оскільки вигоди, що отримаються у майбутньому, завжди мають для людей меншу цінність порівняно з тими вигодами, які одержуються сьогодні.

Другий показник (період окупності) - це відношення загальних витрат (C) до постійного граничного доходу (b) (обчислюється за заданий проміжок часу, місяць або рік). За певних умов величина, зворотня періоду окупності, дорівнює очікуваному внутрішньому коефіцієнту віддачі. Для того щоб це сталося, необхідно, щоб всі витрати доводилися на початковий період часу, а доходи були постійні.

Цей показник зв'язує витрати і доходи, і з його допомогою різні програми інвестування можуть бути приблизно оцінені з точки зору їх відносної ефективності. Критерієм служить вибір інвестиційного проекту з найбільш коротким періодом окупності.

Проте критерій окупності має ряд таких недоліків:

- він не враховує той факт, що витрати і доходи конкурентних альтернативних інвестиційних проектів розділені в часі і мають різні тимчасові характеристики. Аби зробити різні показники тимчасових витрат і прибутку порівнянними, необхідно провести дисконтування;

- абсолютний обсяг чистих доходів в альтернативних проектах може бути різним. Період окупності цього не враховує;

- цим критерієм взагалі не можна скористатися, коли альтернативні інвестиційні проекти взаємно виключають один одного.

Найбільш поширеними інвестиційними критеріями $є$ чиста приведена вартість, співвідношення витрат і прибутку, а також внутрішній коефіцієнт віддачі. Вони можуть дати одні і ті ж результати, але за певних умов:

- ринки капіталу є ринками досконалої конкуренції;

- всі наявні проекти абсолютно обумовлені один від одного;

- між ними не існує взаємної залежності. 
Всі чисті доходи можуть бути реінвестовані при тих же внутрішніх коефіцієнтах віддачі до кінцевої дати самого довгострокового 3 проектів. 3 врахуванням вказаних допущень і даній процентній ставці відсотка, по якій виробляється дисконтування, можна схвалити будь-який інвестиційний проект. Якщо існує декілька фондів для інвестицій, то приймається проект з наступним по величині значенням поточної вартості і так далі, поки фонди не вичерпаються або не залишиться проект з позитивною або нульовою чистою поточною вартістю [7].

Критерій відношення прибутку і витрат можуть бути корисний тоді, коли приймається рішення про інвестиції в ті проекти, для яких відношення поточної вартості доходів до поточної вартості витрат більше одиниці.

Варіантом співвідношення прибутку і витрат $є$ відношення виміру граничних витрат між двома альтернативними проектами.

Внутрішня норма прибутку - це такий процентний показник, який порівнюється із ставкою відсотка, що представляє допустимий коефіцієнт віддачі від суспільних або приватних освітніх інвестицій. Внутрішня норма прибутку - процентна ставка, при якій дисконтована вартість витрат дорівнює дисконтованій вартості доходів.

Аби визначити ефективність проекту, пов'язаного з інвестиціями в освіту, необхідно порівняти витрати на освіту з вигодами від його здобуття. Якщо вигоди перевищать витрати, то індивіду вигідно продовжити навчання [8].

Також, для оцінки ефективності інвестицій в людський капітал можна використовувати показник внутрішньої норми віддачі освіти, при якій поточна вартість майбутніх доходів дорівнює поточній вартості здійснюваних витрат. Вона представляє ту норму доходу, яку можна чекати при реалізації даного інвестиційного проекту [9, С. 85].

У зв'язку з тим, що існує велика кількість показників ефективності інвестицій в людський капітал, слід зазначити, що абсолютно бездоганних критеріїв немає. У кожному конкретному випадку необхідно вивчити конкретні умови, визначити найкращий інвестиційний критерій, який може бути успішно застосований лише в системі взаємопов'язаних критеріїв.

Узагальнюючи методи оцінки ефективності людського капіталу, виділимо ряд важливих проблем:

- причинно-наслідковий залежність не завжди очевидна;

- неможливо однозначно визначити всі витрати, які класифікуються як інвестиції в людський капітал;

- роль людського капіталу може бути прихована через його взаємодії з іншими факторами: адаптацією до нових технологій, вдосконаленням організації праці, більш ефективним розміщенням фі- 
зичного капіталу;

- наявність тривалого лага між вкладенням коштів і отриманням результату;

- труднощі визначення того, які результати відповідають конкретним вкладенням, враховуючи це в масштабі національної економіки, процеси вкладення капіталу в галузі соціальної сфери і процеси отримання віддачі від цих інвестицій безперервні;

- закінчений рівень освіти є вкрай незадовільним показником 3 точки зору ролі знань і навичок;

- існує помилка виміру через відсутність єдності класифікації закінченої освіти в різних країнах;

- диференціація віддачі капіталу від освіти в залежності від території, стажу роботи та інших факторів, які безпосередньо не відносяться до навчання.

Таким чином, основним методом оцінки ефективності інвестицій у людський капітал залишається експертний метод.

Висновки. Таким чином, інвестування в розвиток персоналу $є$ складним економічним процесом. Підприємство, інвестуючи в розвиток персоналу протягом певного періоду часу, очікує отримати майбутні доходи за рахунок зростання продуктивності праці, і як наслідок - збільшення обсягу виробництва продукції (послуг), оптимізації чисельності персоналу, скорочення непродуктивних витрат часу, зростання конкурентоспроможності продукції завдяки покращенню їх якості та оптимізації витрат на їх виробництво. Інвестиції в розвиток людського капіталу - це поліпшення перспектив економічного росту підприємства. Таким чином, основним методом оцінки ефективності інвестицій у людський капітал залишається експертний метод.

У зв'язку з тим, що існує велика кількість показників ефективності інвестицій в людський капітал, слід зазначити, що абсолютно бездоганних критеріїв немає. У кожному конкретному випадку необхідно вивчити конкретні умови, визначити найкращий інвестиційний критерій, який може бути успішно застосований лише в системі взаємопов'язаних критеріїв.

1. Макконелл К. Р., Брю С. Л. Экономикс: принципы, проблемы и политика / пер. с англ. К. : Хагар-Демос, 1993. 785 с. 2. Кирьянов А. В. Виды инвестиций В человеческий капитал и их эффективность. URL: http://www.cfin.ru/bandurin/article/sbrn07/08.shtml. (дата звернення: 15.01.2019). 3. Добрынин А. И., Дятлов С. А., Цыренова Е. Д. Человеческий капитал в транзитивной экономике: формирование, оценка, эффективность использования. СПб. : Наука, 1999. 421с. 4. Малыхина М. Сотрудники - основной капитал компании. Управление персоналом. 2006. № 2(132). С. 1819. 5. Киркпатрик, DL и Киркпатрик JD (2006). Оценка учебных программ. 3-е изд. Сан-Франциско, Калифорния : Berrett-Келер. 6. Базарова Т. Ю., Еремена Б. Л. Концепция «человеческого капитала». URL: 
http://www.aup.ru/books/m152/4_4.htm (дата звернення: 15.01.2019). 7. Невров В. Семь вопросов про инвестиции в персонал. URL: http://www.ou-link.ru/publ/region/2008-orel-prr-24.htm. (дата звернення: 15.01.2019). 8. Яковлева Н. Инвестиции в развитие персонала - как оценить эффективность. URL: http://www.master-class.spb.ru/art-investrazvit/. (дата звернення: 15.01.2019). 9. Матвеева Н. С., Нестеренко О. С. Методы оценки и критерии экономической эффективности человеческого капитала. URL: http://creativeconomy.ru/library/prd31.php. (дата звернення: 15.01.2019). 10. Юданова А. Л. Оценка эффективности инвестиций в высшее образование. Финансы. 2007. № 1. С. 84-85.

\section{REFERENCES:}

1. Makkonell K. R., Briu S. L. Ekonomiks: printsipy, problemy i politika / per. s anhl. K. : Khahar-Demos, 1993. 785 s. 2. Kirianov A. V. Vidy investitsyi v chelovecheskii kapital i ikh effektivnost. URL: http://www.cfin.ru/bandurin/article/sbrn07/08.shtml. (data zvernennia: 15.01.2019). 3. Dobrynin A. I., Diatlov S. A., Tsyrenova E. D. Chelovecheskii kapital V tranzitivnoi ekonomike: formirovanie, otsenka, effektivnost ispolzovaniia. SPb. : Nauka, 1999. 421s. 4. Malykhina M. Sotrudniki - osnovnoi kapital kompanii. Upravlenie personalom. 2006. № 2(132). S. 18-19. 5. Kirkpatrik, DL i Kirkpatrik JD (2006). Otsenka uchebnykh prohramm. 3-e izd. San-Frantsysko, Kalyfornyia : Berrett-Keler. 6. Bazarova T. Yu., Eremena B. L. Kontseptsiia «chelovecheskoho kapitala». URL: http://www.aup.ru/books/m152/4 _4.htm (data zvernennia: 15.01.2019). 7. Nevrov V. Sem voprosov pro investitsii v personal. URL: http://www.oulink.ru/publ/region/2008-orel-prr-24.htm. (data zvernennia: 15.01.2019). 8. Yakovleva N. Investitsii v razvitie personala - kak otsenit effektivnost. URL: http://www.master-class.spb.ru/art-investrazvit/. (data zvernennia: 15.01.2019). 9. Matveeva N. S., Nesterenko O. S. Metody otsenki i kriterii ekonomicheskoi effektivnosti chelovecheskoho kapitala. URL: http://creativeconomy.ru/library/prd31.php. (data zvernennia: 15.01.2019). 10. Yudanova A. L. Otsenka effektivnosti investitsii $v$ vysshee obrazovanie. Fynansy. 2007. № 1. S. 84-85.

Рецензент: к.е.н., професор Кушнір Н. Б. (НУВГП)

Onokalo V. H., Candidate of Economics (Ph.D.), Associate Professor (National University of Water and Environmental Engineering, Rivne)

\section{THEORETICAL ASPECTS THAT THE ASSESSMENT OF EFFECTIVENESS OF INVESTMENT IN ROSVITOK PERSONNEL PIDDPRIMSTVA}

The article comprehensively covers the theoretical aspects of the various approaches to evaluating the effectiveness of investment in personnel development of the enterprise. The main problem faced by 
modern enterprises, is to evaluate the effectiveness of investments in the enterprise personnel. As noted by the theorists of human capital, expenditures that increase the productive qualities and characteristics of the individual can be viewed as an investment, as current expenditures are incurred with the expectation that they will be repeatedly offset by an increased revenue stream in the future.

One of the most important components of investment in human capital in all countries is the cost of in-service training. To assess the effectiveness of investments in human capital using a number of criteria and indicators. In the economic literature, the following indicators of efficiency of investments in human capital: maximizing the difference between profit and costs; the payback period (return) of investments net current (present) value, the ratio of costs and profits; the ratio of the difference between the marginal revenue to the marginal cost difference annual net income, internal rate of return.

It is shown that due to the fact that there are a large number of indicators to assess the effectiveness of investments in the personnel of the enterprise, should in every case examine the specific conditions to determine the best investment criterion, which can be successfully applied only in a system of interrelated indicators.

Key words: investments, human capital, personnel of enforcement. Keywords: investments, human capital, personnel of enforcement.

Онокало В. Г., к.э.н., доцент (Национальный университет водного хозяйства и природопользования, г. Ровно)

\section{ТЕОРЕТИЧЕСКИЕ АСПЕКТЫ И ОЦЕНКА ЭФФЕКТИВНОСТИ ИНВЕСТИЦИЙ В РАЗВИТИЕ ПЕРСОНАЛА ПРЕДПРИЯТИЯ}

В статье комплексно освещаются теоретические аспекты различных подходов к оценке эффективности инвестиций в развитие персонала предприятия. Показано, что в связи с тем, что существует большое количество показателей для оценки эффективности инвестиций в персонал предприятия, следует в каждом случае изучить конкретные условия, определить наилучший инвестиционный критерий, который может быть успешно применен только в системе взаимосвязанных показателей.

Ключевые слова: инвестиции, человеческий капитал, персонал предприятия. 